\title{
Women and Party Politics in Western Europe
}

\author{
Joni Lovenduski, Southampton University
}

\begin{abstract}
A common teaching problem in the area of gender and politics arises from the diverse backgrounds of the students who tend to take these courses. Often classes contain students with an interest in gender who know nothing about political science and political science students who know nothing about gender. When the focus is on European politics, these problems are compounded by the difficulty of making sense without generalizing to the point where the diversity of Europe is lost. Although scholars such as Kaplan (1992) and Norris (1993) have offered useful classification schemes which bring an intellectual "order" into European gender politics, in both cases, a considerable knowledge about European politics is assumed in their work. Moreover, these pieces do not work well in every class setting. My solution is to try to work thematically by using, for example, students' home country (or the country in which I am teaching and they are learning) and comparing it to a different country. In this way a package of information about two political systems can be offered along with some introduction to techniques of comparison.
\end{abstract}

In this essay, I offer a comparative case study which deals with the impact of party politics on the representation of women. As the main channel between mass and elite politics, parties are institutions that are at the center of European political life. Governments consist of party leaders, and voters indicate their preferences by choosing between candidates who are nominated by parties. Party manifestos indicate and shape the political agenda. Parties are important for women. By the beginning of the 1980s, it was clear that the key to the political representation of women in Europe was their influence in party politics. The countries with strong representation of women all had political parties with strong and actice affirmative action policies to equalize the repre- sentation of men and women in their national and local legislatures. As Leslie Eliason notes, the Nordic states in particular have used quotas, targets, training schemes, and other instruments of affirmative action to bring more women into party politics. In other countries, similar trends became apparent as parties began to promote women and sex equality in their programs and political recruitment strategies.

These phenomena raise many interesting questions for feminists and for political scientists. Here, I want to concentrate on the circumstances in which party strategies to promote women get established. In particular, I want to try to answer two questions:

1. Are some political institutions more hospitable to the promotion of women than others?

2. Are parties more likely to promote women where a strong women's movement is present?

To answer these questions, we must look closely at the progress of women in particular party systems. Ideally, we should look at all European liberal democracies or all OECD states. This essay examines the examples of Great Britain and West Germany during the 1980s. They offer a combination of the two main strategies of comparative research: the most-similar strategy and the most-different strategy.

They are similar in three important ways: (1) they have class-based party systems dominated by two large parties; (2) they both have strong social democratic parties that underwent reform and modernisation during the 1980s; and (3) both experienced a second wave of feminism that began in the 1970s. They are different in two important respects: (1) Great Britain is unitary and West Germany is federal; and (2) Great Britain has a majoritarian electoral system and West Germany has a proportional representation system.
The growth of women's representation in both systems during the 1980s is the issue examined here. Neither system had a good record of women's representation in the legislature prior to 1980. In Britain, during the $1970 \mathrm{~s}$, women comprised, on average, $3.7 \%$ of Parliament. In West Germany, the average percentage of women deputies to the Bundestag was $6.5 \%$. During the $1980 \mathrm{~s}$, there was a shift in both countries. In Britain, the proportion rose to $6.5 \%$ by 1987 . In West Germany, it rose to $15.4 \%$. (At the end of 1991 , Britain was at $6.8 \%$, and the Bundestag of the re-unified Germany was at $20.4 \%$ ) Thus, while both systems experienced significant change, in Germany change was greater with women's representation increasing almost half as much again as in Britain.

There are two developments that need to be explained: why there was change? and why did the change occur at different rates? Remember that these initial questions are about the effects of political institutions and of the women's movements in the two systems. In order to proceed, it is necessary to present more information on the relevant political institutions and women's movements. The British institution is a "two-party" system that actually sends representatives from between five and seven political parties to the House of Commons. It is regarded as a two-party system because together the Labour and the Conservative parties consistently win over $90 \%$ of the parliamentary seats for which they present candidates. Two-party competition is institutionalized by a first-past-the-post electoral system based on single-member constituencies. The system has a tendency to exaggerate majorities and impede the entry of new parties unless their support is geographically concentrated. The result is that Britain has a high threshold of representation. This means that it is hard for new 
political actors to win powerful positions.

There are three reasons for this. First, British parties are organized around electoral systems; thus, the second reason, the important level of British party organization is at the constituency level where candidates are selected by constituency activists who rarely allow party leaderships to interfere. Third, high levels of incumbency make turnover low. A further effect of the two-party system that reduces its representative capacity arises from the division of the electorate into two class-based blocs. This means that parties traditionally organize their appeal to the electorate on assumptions about class loyalties. They try to pick up their majorities from voters with weak class loyalties. In other words, they concentrate on the center of the ideological spectrum and avoid its extremes. British feminism operates mainly on the left of Britain's party system. It is a comparatively wellestablished movement with strong socialist inclinations (Lovenduski and Randall 1993).

West Germany was also dominated by two large political parties, the Social Democratic Party (SPD) and the Christian Democratic Party (CDU/CSU). The voting system is the additional member system based on regional lists. The party distribution of the vote almost perfectly reflected the party distribution of Deputies in the Bundestag. West

Germany had a comparatively low threshold of political representation. The Basic Law set hurdles whereby parties needed to secure $5 \%$ of the vote before they were entitled to seats, but otherwise barriers to new entrants were minimal. The openness of the electoral system and the lower levels of incumbency compared to Great Britain offered greater opportunities to change the composition of the Bundestag as there were proportionately more vacancies in any given election. Constituencies played a smaller role than in Britain. Party lists were also drawn up by the national and regional leaderships, hence party managers had more leverage over the composition of their slate. They also had an incentive to present a balanced ticket because several candi- dates are presented to the electorate at the same time.

However, as in Britain, the class and ideological basis of voting was well established. Habitually, parties appealed for their extra votes to voters with cross-class or weak class loyalties. Elections in this system tend to be closely fought and won at the margins, small swings resulted in changes of government. At the same time, the more open set of political institutions was accompanied by a feminist movement that was not so interested in political institutions. Unlike the movement in Britain, the West German second wave feminist movement was separatist in its inclinations, hence feminist organisation in the political parties was less consistent.

In neither system was there much incentive for a political party to improve its representation of women unless one of three things happened: (1) if it became clear that to do so would secure the party's electoral majority; (2) if it became clear that to fail to do so would lose electoral support; or (3) if the system changed. During the $1980 \mathrm{~s}$, all three happened in both countries. In Britain, prior to the 1980s neither the Labour nor the Conservative Parties paid much attention to women members and voters. Annual women's conferences were social occasions and no systematic efforts were made to increase the number of women MPs, even though it was known that voters did not penalize women candidates.

At the beginning of the 1980 s, the neglect of women by parties began to go rapidly out of fashion. It became impossible to avoid evidence of the party pursuit of women in the wake of three developments: (1) women were no longer more likely than men to vote Conservative; (2) Labour women strengthened their organization and put increased pressure on the party to take their needs into account; and (3) a third party appeared on the scene in 1981 and made explicit efforts to win women's votes with strategies that included policies to ensure that women got nominated. Thus, a process of competitive bidding for the women's vote began. Labour responded immediately and vocally and instituted a wide range of new strategies to promote women's rights and women's visibility in the party, including a Shadow Ministry of Women that was promised to be a Ministry for Women with cabinet status, quotas of women on party bodies, and a quota of $50 \%$ women in the Parliamentary Labour Party within three General Elections. The Conservatives were slower, but gained momentum as their chances for re-election appeared to recede at the end of the decade. They pledged to increase the number of women candidates, introduced a women's portfolio into ministerial assignments, and began investigating ways of increasing the number of Conservative Women MPs.

The West German story is slightly different. During the 1980 s, women in the West German electorate became more volatile. According to Eva Kolinsky (1991 and 1993), young women voters were particularly disaffected. But political leaders did not at first respond well. In the 1983 General Elections, the Social Democratic Party (SPD) strategy was to design its poster of candidates so that the women were all at the front of the photograph. Without a strong feminist presence in the parties, it seemed that, despite West Germany's low threshold of representation, there would be little change in women's representation there. However, an important opportunity was presented by the fact that the party system changed. As in Britain, party competition increased temporarily.

When the Green Party appeared on the political horizon it was able to mobilize a feminist constituency that had been ignored by the other parties. The Greens had a good record on the representation of women in their organization and in the Landtage and they gained a high profile for their feminism when six women took the leadership of the parliamentary wing of the party in 1985. As in Britain, the other parties responded immediately. The Christian Democratic Union (CDU) used their 1985 Annual Congress at Essen to highlight the situation of women and the role of CDU women. In an political manoeuvre, the CDU invited the rival SPD to send delegates 
to these discussions. Meanwhile, women in the SPD who were radicalised by the appearance of the Greens in the Bundestag stepped up their pressure on the party to implement strategies of positive action in respect of women candidates.

Here too there was an outbreak of competition for women's support. The Greens led, pledging that 50\% of its candidates at all levels of elections would be women, as would $50 \%$ of party office holders. In response, the CDU offered to nominate women in proportion to their membership in the party and the SPD promised that, by the 1990 s, half of its candidates would be women. In 1987, a record number of women candidates were nominated and subsequently elected. In 1990, the SPD pledged to enforce a $40 \%$ quota in its party organization by 1994, and the Liberals promised to nominate women in proportion to their membership in the party. Only the CSU refrained from such pledges.

What may we conclude from this case? There is strong evidence that political institutions matter. West
German women out-performed British women despite a later start and a weaker feminist movement. The low West German threshold of representation is the key. All of the other factors were either similar or suggested another outcome. Proportional electoral systems with high district magnitudes offer opportunities to alter party candidate profiles. They tend to be associated with party systems in which party managers can determine candidate selection. When demand for change comes, women candidates may be placed in good places on party lists and that is what West German party managers did.

But this does not mean that feminism does not matter. In both systems, established institutions became carriers of feminist ideas. In both systems, the strongest effects were in the parties in which women organized to pressure the parties from the inside. We may conclude that the institutions of representation matter more than the strength of feminist organization, but feminist organization is also important to the politics of increasing women's political visibility and power.

\section{References}

Kaplan, Gisela. 1992. Contemporary West European Feminism. London: UCL Press \& Allen \& Unwin.

Kolinsky, Eva. 1993. "Party Change and Women's Representation in Unified Germany." In Gender and Party Politics eds. Joni Lovenduski and Pippa Norris, 11346. London: Sage.

Kolinsky, Eva. 1991. "Women's Quotas in West Germany." West European Politics. 14(1).

Lovenduski, Joni and Vicky Randall. 1993. Contemporary Feminist Politics. Oxford: Oxford University Press.

Norris, Pippa. 1993. "Conclusions: Comparing Legislative Recruitment." In Gender and Party Politics, eds. Joni Lovenduski and Pippa Norris, 309-30. London: Sage.

\begin{abstract}
About the Author
Joni Lovenduski is professor of politics at Southampton University. She is author of Women and European Politics, (1986) co-author of Political Reconitment (1994), Contemporary Feminist Politics (1993), and Politics and Society in Eastern Europe (1987). She was co-Director of the British Candidate Study from 1988 to 1992. She was a founding convener of the Standing Group on Women and Politics of the European Consortium for Political Research and of the Women and Politics Group of the Political Studies Association of the UK.
\end{abstract}

\section{Integrating Women into the Study of European Politics}

\section{Sonja Elison, Gonzaga University}

Classes on European politics should include women because women represent over $50 \%$ of the population in most Western democratic societies, and their votes are quite consequential. European politicians know this; so should students of political science. If we ignore the influence of women's votes on the strategies of politicians and parties, we distort the reality of democracy. Throughout the 1980s and the 1990s, European political systems responded to women through a variety of demo- cratic mechanisms, such as quotas and party conferences. Integrating gender into the European politics curriculum is essential when covering electoral systems, social movements, party politics (especially of the right), religion, and transitions to democracy. Below, I discuss models for such integration using the kind of cases discussed by Joni Lovenduski. For me, using these cases in the undergraduate classroom has been highly effective.

\section{Exercise 1: Electoral Systems}

For many undergraduates, one of the oddest features of European politics is proportional representation (PR) and its relation to multiparty systems. To help students understand the difference between voting in a majoritarian system and voting in a PR system, I conduct mock elections. The students suggest parties for which they want to vote. When we do a PR system, the students often have a hard time envi- 